\title{
Increased Fetuin-B Levels are Associated with Carotid Intima Media Thickness and Hormonal-Metabolic Disturbances in Women with Polycystic Ovary Syndrome
}

\author{
Artan Fetuin-B Seviyeleri, Polikistik Over Sendrom’lu Kadınlarda Karotis İntima Media Kalınlığı \\ ve Hormonal Metabolik Bozukluklarla İlişkilidir \\ Aslı GULER ${ }^{1}$, Gokcen Unal KOCABAS ${ }^{2}$, Cetin IMAMOGLU ${ }^{3}$, Yasemin ALAN ${ }^{4}$ \\ 1. Department of Family Physician, Izmir Bozyaka Training and Research Hospital, 35170 Bozyaka, Izmir, Turkiye \\ 2. Division of Endocrinology and Metabolism, Dept. of Internal Medicine, Bozyaka Training and Research Hosp., Izmir, Turkiye \\ 3. Department of Radiology, Izmir Bozyaka Training and Research Hospital, 35170 Bozyaka, Izmir, Turkiye \\ 4. Department of Obstetrics and Gynecology, İzmir Metropolitan Municipality Eşrefpaşa Hospital,35110, İzmir, Turkiye
}

\section{ABSTRACT}

Objective: Fetuin-B is a novel peptide hormone involves in energy metabolism, atherosclerosis and reproductive system. Polycystic ovary syndrome (PCOS) is a reproductive and metabolic disorder associated with increased cardiovascular risk factors. We aimed to ascertain whether circulating fetuin-B levels were altered in women with PCOS and whether there was any association between fetuin- $B$ and hormonal-metabolic parameters as well as carotid intima media thickness (CIMT).

Material and Methods: Eighty women with PCOS and 80 ageand BMI-matched controls without PCOS were recruited to this cross-sectional study. Circulating fetuin-B levels were measured by ELISA. Metabolic- hormonal parameters and CIMT of recruited subjects were also determined.

Results: Circulating fetuin-B levels were significantly elevated in women with PCOS compared to controls (409.54 \pm 32.51 vs. 325.53 $\pm 26.86 \mathrm{ng} / \mathrm{ml}, P<0.001)$. PCOS subjects with insulin resistance showed significantly elevated circulating fetuin-B levels compared to those PCOS subjects without insulin resistance $(416.03 \pm 30.41$ vs. $399.27 \pm 33.56 \mathrm{ng} / \mathrm{ml}, P=0.024)$. Overweight/obese women had significantly higher circulating fetuin-B levels than lean subjects in PCOS groups (416.32 \pm 30.99 vs. $400.82 \pm 32.77 \mathrm{ng} / \mathrm{ml}, P=0.033)$. Fetuin-B levels positively correlated with BMI, homeostasis model assessment of insulin resistance (HOMA-IR), free-androgen index (FAI), high sensitivity $C$-reactive protein (hs-CRP), triglycerides and CIMT in PCOS subjects whereas fetuin-B negatively correlated with high density lipoprotein cholesterol (HDL-C). Moreover binary logistic regression analysis revealed that the risk of having $P C O S$ was increased in parallel with elevation of fetuin-B levels.

Conclusion: Circulating fetuin-B levels were significantly increased in PCOS subjects and fetuin-B levels were closely related to cardiovascular risk and hormonal-metabolic disturbances in women with PCOS.

Keywords: polycystic ovary syndrome, fetuin- $B$, insulin resistance, body mass index, carotid intima media thickness

\section{$\ddot{O Z E T}$}

Amaç: Fetuin-b enerji metabolizmasl, ateroskleroz ve üreme sisteminde rol oynayan yeni bir peptid hormonudur.Polikistik over sendromu (PKOS) üreme ve metabolik sistemleri içeren artmış kardivasküler risk tasıyan bir hastalıktır.Bu çalısmada PKOS'lu kadınlarda dolaşımdaki Fetuin-b düzeyinde değişiklik olup olmadığını ve Fetuin-b düzeyi ile hormonal-metabolik parametreler ile Karotis intima media kalınlı̆̆ı (CIMT) arasında bir ilişki olup olmadiğını tespit etmeyi amaçladık.

Gereç ve Yöntemler: Kesitsel çalıșmamıza 80 PKOS'lu kadın alınmıştır. Kontrol grup olarak 80 tane yaş ve BMI uyumlu kadın çalışmaya alınmıștır.

\section{Contact:}

Corresponding Author: Yasemin ALAN, MD.

Adress: Department of Obstetrics and Gynecology, İzmir Metropolitan Municipality Eșrefpaşa Hospital, 35110 Konak, Izmir, Turkiye

e-Mail: jasminalann@hotmail.com

Phone: +90 (533) 3952068

Submitted: 23.01 .2020

Accepted: 30.04 .2020

DOI: http://dx.doi.org/10.16948/zktipb.679178
Dolașımdaki Fetuin-b seviyeleri ELISA yöntemi ile ölçüldï. Ayrica deneklerin metabolik hormonal parametreleri ve CIMT'si de belirlenmiştir.

Bulgular: Dolaşımdaki Fetuin-b düzeyleri PKOS'lu kadınlarda kontrollere göre anlaml derecede yüksek bulundu (409.54 + 32.51 vs. $325.53 \pm 26.86 \mathrm{ng} / \mathrm{ml}, P<0.001$ ). Insülin direncine sahip PKOS denekleri, insülin direncine sahip olmayan PCOS öznelerine göre anlaml derecede yüksek dolașim Fetuin-B seviyeleri gösterdi (416.03 \pm 30.41 vs. $399.27 \pm 33.56 \mathrm{ng} / \mathrm{ml}, P=0.024)$.

Aşırı kilolu / obez kadınlarda PKOS gruplarında düşük kilolu deneklerden anlaml derecede daha yüksek dolasımdaki Fetuin-b düzeyleri vard $(416.32 \pm 30.99$ vs. $400.82 \pm 32.77 \mathrm{ng} / \mathrm{ml}, P$ $=0.033)$.Fetuin- $B$ düzeyleri BKI, insülin direncinin homeostaz modelinin değerlendirilmesi (HOMA-IR), free-androgen index (FAI), high sensitivity $C$-reactive protein ( $h s-C R P)$ trigliseritler ve CIMT ile pozitif korelasyon gösterir iken yüksek yoğunluklu lipoprotein kolesterol (HDL-C) ile negatif korelasyon göstermektedir. Ayruca ikili lojistik regresyon analizi, PKOS olma riskinin Fetuin-B seviyelerinin yükselmesine paralel olarak arttı̆̆ını ortaya koydu.

Sonuç: Dolaşımdaki Fetuin-B düzeyleri PKOS'lu hastalarda anlamlı olarak artmış olup Fetuin-B düzeyleri PKOS'lu kadınlarda kardiyovasküler risk ve hormonal metabolik bozukluklarla yakından ilişkilidir.

Anahtar Kelimeler: polikistik over sendromu, Fetuin-B, insulin direnci, beden kitle indeksi, Karotis intima media kalınlı̆̆

\section{INTRODUCTION}

Polycystic ovary syndrome (PCOS) is a complex metabolic and reproductive disease, commonly occurred in women with reproductive age with the prevalence of $6-18 \%$ [1]. Ovulatory dysfunction, polycystic ovaries, biochemical (elevated androgens) and/or clinical (hirsutism and/or acne) hyperandrogenisms are characteristic features of PCOS. PCOS subjects are associated with a variety of metabolic abnormalities including insulin resistance, type 2 diabetes mellitus (T2DM), obesity and dyslipidemia. Moreover, affected women tend to have increased risk of cardiovascular disorders [2]. Insulin resistance and consequently developed hyperinsulinemia are known to play important roles in development of PCOS although the pathogenesis of the disorder is not fully understood yet $[3,4]$.

Fetuin-B is a novel pluripotent peptide hormone which is a member of the cystatin super family of cysteine protease [5]. It is secreted from various tissues such as liver and adipose tissue [6]. Growing evidence suggest that fetuin-B plays a crucial role in glucose metabolism. In a preclinical study, it was reported that fetuin-B impaired insulin action in hepatocytes and it also decreased insulin-stimulated glucose uptake in myotubes in a time and 
dose dependent manner. Moreover, it was demonstrated that fetuin-B decreased insulin-mediated suppression of gluconeogenesis in hepatocytes [7]. Various clinical studies suggested that there was a link between fetuin-B and metabolic disorders associated with insulin resistance. Fetuin-B levels were found to be elevated in subjects with T2DM, non-alcoholic fatty liver disease (NAFLD) and gestational diabetes mellitus (GDM) [ 8]. In another study, subjects with T2DM had increased levels of fetuin-B compared to controls and elevated levels of fetuin-B were associated with first-phase glucose-stimulated insulin secretion, insulin resistance as well as lipid metabolism [9]. Moreover, the link between atherosclerosis and fetuin-B has been reported [10]. Fetuin-B increases migration of monocytes and macrophages in the vascular plaque and it also increases vascular plaque vulnerable [10]. In addition, the role of fetuin-B in reproductive system has also been reported [11].

Due to the lack of sufficient data regarding to the link between fetuin-B and PCOS, we aimed to discover altered levels of fetuin-B in PCOS women. Furthermore, we aimed to investigate the association between fetuin-B and hormonal-metabolic disturbances as well as carotid intima media thickness (CIMT).

\section{MATERIAL AND METHOD}

\section{Ethics statement}

The local ethics committee of Bozyaka Training and Research Hospital approved this study (No: 8 / 21.06.2016). We took the subjects' oral and written informed consent. The study fitted to the Declaration of Helsinki Principles (revised in 2008).

\section{Subjects and study design}

The trial was planned as a cross-sectional study and was lasted from August 2016 to March 2017 in the Department of Endocrinology, Bozyaka Training and Research Hospital, Izmir, Turkey. We recruited 80 subjects with PCOS and 80 age- and body mass index (BMI)-matched subjects with normal menstrual cycles who had visited our clinic and met the inclusion and exclusion criteria. A single expert evaluated clinical and anthropometric variables of all subjects.

\section{PCOS group}

PCOS was diagnosed in this study according to the 2003 Rotterdam consensus criteria [12]. We only selected those patients with all three following criteria in the PCOS group for reaching a proper homogeneity (after excluding other causes of hyperandrogenism and ovulatory dysfunction): 1) Oligoand/or anovulation, 2) Clinical and/or biochemical signs of hyperandrogenism - The Ferriman-Gallwey $[\mathrm{FG}]$ method was used to determine hirsutism [13]. Subjects were considered hirsute with FG score of $\geq 8$. Biochemical hyperandrogenism was defined as an increase (greater than the normal range) in the serum concentrations of free-testosterone (normal values: $2.9-31.8 \mathrm{ng} / \mathrm{dl}$ ) and/or total testosterone (normal values: $0.15-0.7 \mathrm{ng} / \mathrm{ml}$ ), and/or a dehydroepiandrosterone sulfate (DHEA-SO 4 ; normal values:
10-248 $\mu \mathrm{g} / \mathrm{dl})$, 3) Typical ultrasonographic finding of polycystic ovaries (with one ovary being sufficient for diagnosis), defined as the presence of $\geq 12$ follicles measuring 2-9 $\mathrm{mm}$ in diameter or an ovarian volume of $>10 \mathrm{ml}$ (without a cyst or dominant follicle in either ovary).

\section{Control group}

Control subjects were chosen from healthy women who had visited the gynecology or endocrinology department for routine checkup or from hospital employees and university students. All volunteers for the control group had regular menstrual cycles and they had no connected health problems or signs of hirsutism or acne or hyperandrogenism.

\section{Exclusion criteria}

The exclusion criteria were 1) other causes of irregular menstrual cycles and/or androgen excess (i.e. Cushing's syndrome, hyperprolactinemia, congenital adrenal hyperplasia, or other diseases of the adrenal gland, thyroid disorders, galactorrhea, breastfeeding and pregnancy); 2) impaired glucose tolerance or type $1 /$ type 2 diabetes (a $75 \mathrm{~g}$ oral glucose tolerance test was performed for all participants); 3 ) hypertension, hyperlipidemia, active or chronic liver or renal failure, or congestive heart failure; 4) a history of coronary artery disease, GDM, or acute infection (within the preceding 14 days); 5) presence of any chronic inflammatory and autoimmune disease; 6) known malignancy; 7) hormonal contraception and/or anti-androgen therapy (within the preceding 6 months); and 8 ) BMI $<18.5 \mathrm{~kg} / \mathrm{m} 2$ or BMI $\geq 35 \mathrm{~kg} / \mathrm{m} 2$, age $<18$ or $>35$ years; 9) subjects having NAFLD (diagnosed with ultrasound) and 8) The use of medications for dyslipidemia, hypertension, hyperglycemia, insulin resistance or obesity.

\section{Anthropometric evaluation}

A detailed history was taken from the individuals included in the study. Anthropometric measurements were performed (age, weight, height and waist circumference) following general physical examinations of the subjects; height (centimeter) and weight (kilogram) of the barefoot subject were measured as they were in daily clothes. BMI was calculated using the following formula: weight $(\mathrm{kg}) /$ square meter of height $\left(\mathrm{m}^{2}\right)$. Waist circumference $(\mathrm{cm})$, midway between the lower rib margin and the iliac crest at the end of a gentle expiration was measured. After a rest period of at least $15 \mathrm{mi}-$ nutes, blood pressure of the subjects was also measured in their sitting position. The average of three measurements was calculated.

\section{Biochemical evaluation}

Venous blood samples were gathered from all participants in the early follicular phase (day 3 to 5) of spontaneous or progesterone-induced menses, in the morning (between 08:00-09:00) after at least a 10-hour fasting period. The blood samples were put at room temperature for at least 30 minutes to be clotted. The samples were then centrifuged for at $2000 \times \mathrm{g}$ for 15 minutes and serum aliquots were at $-80^{\circ} \mathrm{C}$ for fetuin-B analysis. Moreover, fasting blood glucose (FBG), glycated hemoglobin A1C (HbA1C), serum insulin, high-density lipoprotein cholesterol (HDL-C), total triglyceride, cholesterol and testosterone, DHEA-S, luteinizing hormone 
(LH), sex hormone of binding-globulin (SHBG), follicle-stimulating hormone (FSH), estradiol (E2), 2-h plasma glucose following 75-g OGTT (2-h OGTT) and high-sensitivity of CRP levels were measured. Serum FBG, 2-h OGTT and hs-CRP, total cholesterol, triglycerides and HDL-C were measured using an auto-analyzer (Olympus AU 2700 Beckman Coulter Inc, CA, USA) with its dedicated kits (Beckman Coulter Inc, CA, USA). The levels of low-density lipoprotein cholesterol (LDL-C) were measured using the following formula: LDL-C = total cholesterol - (HDL-C + triglycerides/5). Serum insulin levels were measured using chemiluminescent microparticle immunoassay (CMIA) with its dedicated kits (Beckman Coulter Inc, CA, USA) and an auto-analyzer (UniCel DxI 800, Beckman Coulter Inc, CA, USA). High-performance liquid chromatography (Variant II Turbo, Bio-Rad, CA, USA) was used to measure HbA1C levels. The levels of total testosterone, SHBG LH, FSH, E2, DHEA-S, were also measured using CMIA (UniCel DXI 800, Beckman Coulter Inc., CA, USA). We calculated FAI by the following formula: (total testosterone $/$ SHBG) $\times 100$. We used the homeostasis model assessment of insulin resistance (HOMA-IR) to calculate insulin resistance as follows: fasting insulin $(\mu \mathrm{U} / \mathrm{ml}) \times$ fasting glucose $(\mathrm{mg} / \mathrm{dL}) / 405[14]$.

\section{CIMT Measurement}

CIMT of all subjects was measured using high-resolution ultrasound (Toshiba Aplio 300, Toshiba medical systems Corporation, Tokyo, Japan) with $12-\mathrm{MHz}$ linear type B-mode probe. A single specialized doctor, who was blind to the patient's clinical data, performed ultrasound analyses. The CIMT was measured in the prone position (with head extended and turned to the opposite direction) as the distance between the leading edges of the lumen interface and the media-adventitia interface at $10 \mathrm{~mm}$ proximal to the bifurcation in a plaque-free wall of the left and right common carotid arteries was considered. The CIMT value was expressed as an average of maximal CIMT from both common carotid arteries [15].

\section{Measurement of circulating fetuin-B by ELISA}

Serum fetuin-B levels (Sunred Bio, Shanghai, China) following the manufacturer's protocol were measured using commercially available ELISA kits, the intra-assay CV was $<6 \%$ and the inter-assay CV was $<8 \%$. All samples were analyzed in duplicate. The assays were highly sensitive and specific to human fetuin-B with no significant cross-reactivity or interference.

\section{STATISTICAL ANALYSIS}

\section{Power analysis}

The power analysis was performed using $\mathrm{G}$ Power 3.0.10 for Windows (Heinrich-Heine-Universität Düsseldorf, Düsseldorf, Germany) [16]. According to the results of circulating fetuin-B levels in our pilot study, the required size of the study population was calculated to be 71 subjects per group $(\alpha=0.05$ and the study power $=0.90)$.

All analyses were performed using the Sta- tistical Package for the Social Sciences software version 18.0 (SPSS Inc. Chicago, IL, USA). Normal distribution of the variables was tested using the Kolmogorov-Smirnov test. Normally distributed continuous variables were presented as mean \pm standard deviation (SD). Demographic and laboratory characteristics of the studied women with and without PCOS were compared using independent samples t-test. Pearson's correlation analysis was used to discover the relation of fetuin-B with other variables. To identify independent relationships between fetuin-B levels and correlated parameters, multiple linear regression analyses were performed. All independent variables in the multiple linear regression were tested for multicollinearity. If the variance inflation factor (VIF) exceeded 2.5, the variable was considered to be collinear. Therefore, waist circumference, FBG, insulin, total testosterone and SHBG were not included in the model. We calculated odds ratio (OR) to explore whether there was a link between fetuin-B levels (tertile) and having PCOS using multivariate logistic regression analysis. We added potential confounders such as age, BMI, HOMA-IR and FAI into the model for a proper adjustment. Model compatibility was analyzed using the Hosmer and Lemeshow test in all cases and the analysis revealed that the models were compatible $(\mathrm{P}>0.05)$. All reported confidence interval (CI) values were calculated at the $95 \%$ level. A two-sided $\mathrm{P}$ value $<0.05$ was considered statistically significant.

\section{RESULTS}

\section{Clinical and laboratory characteristics of the study population}

The comparative demographic and laboratory parameters of the studied women, with and without PCOS, are given in Table 1.

Circulating fetuin-B levels were significantly elevated in women with PCOS compared to controls (409.54 \pm 32.51 vs. $325.53 \pm 26.86 \mathrm{ng} / \mathrm{ml}, \mathrm{P}<0.001)$ (Figure 1A).

We divided PCOS patients into two subgroups as being insulin resistant or not (HOMA-IR $>2.71$ and HOMA-IR $\leq 2.71$ ) [17]. (27). Out of 80 subjects, 49 subjects were diagnosed as being insulin resistant. As shown in Figure 1B, PCOS subjects with insulin resistance had significantly elevated circulating fetuin-B levels compared to those PCOS subjects without insulin resistance $(416.03 \pm 30.41$ vs. $399.27 \pm 33.56 \mathrm{ng} / \mathrm{ml}, \mathrm{P}=0.024)$. We next divided PCOS subjects into two subgroups according to their BMI levels $\left(<25 \mathrm{~kg} / \mathrm{m}^{2}\right.$ and $\left.\geq 25 \mathrm{~kg} / \mathrm{m}^{2}\right)$. There were 35 subjects with BMI $<25 \mathrm{~kg} / \mathrm{m}^{2}$ and $45 \mathrm{sub}-$ jects with $\mathrm{BMI} \geq 25 \mathrm{~kg} / \mathrm{m}^{2}$. We compared fetuin-B levels in PCOS subjects according to their BMI. As shown in Figure 1C, overweight/obese women had significantly higher circulating fetuin-B levels than lean women in PCOS groups $(416.32 \pm 30.99$ vs. $400.82 \pm 32.77 \mathrm{ng} / \mathrm{ml}, \mathrm{P}=0.033)$. Insulin levels, FBG, HOMA-IR, hs-CRP, triglycerides were found to be elevated whereas HDL-C levels were found to be decreased in PCOS subjects with respect to controls. Moreover, CIMT was higher in subjects with PCOS compared to controls. 


\section{Correlation of fetuin-B with clinical parameters}

We next analyzed the relationship between circulating fetuin-B levels and other parameters using Pearson's correlation (Table 2).

Circulating fetuin-B Levels positively correlated with BMI, waist circumference and hs-CRP in both control and PCOS groups. Moreover, fetuin-B levels positively correlated with insulin, FBG, HOMA-IR, triglycerides, total testosterone, FAI and

Table 1: Comparison of the demographic and laboratory characteristics of the subjects.

\begin{tabular}{|c|c|c|c|}
\hline Variables & $\begin{array}{c}\text { PCOS } \\
n=80\end{array}$ & $\begin{array}{c}\text { Controls } \\
\mathrm{n}=80\end{array}$ & $\mathrm{P}^{\mathrm{a}}$ \\
\hline Age, years & $27.07 \pm 4.53$ & $26.50 \pm 4.43$ & 0.429 \\
\hline BMI, $\mathrm{kg} / \mathrm{m}^{2}$ & $27.45 \pm 4.41$ & $27.13 \pm 4.27$ & 0.635 \\
\hline Waist circumference, $\mathrm{cm}$ & $89.45 \pm 10.20$ & $87.80 \pm 9.46$ & 0.290 \\
\hline $\mathrm{SBP}, \mathrm{mmHg}$ & $108.37 \pm 12.58$ & $106.63 \pm 11.51$ & 0.361 \\
\hline DBP, mmHg & $73.65 \pm 6.88$ & $73.17 \pm 5.60$ & 0.632 \\
\hline Ferriman-Gallwey score & $14.44 \pm 2.85$ & $4.28 \pm 1.20$ & $<0.001^{*}$ \\
\hline FBG, mg/dl & $85.17 \pm 7.83$ & $81.90 \pm 6.30$ & $0.004 *$ \\
\hline 2-h OGTT, mg/dl & $122.65 \pm 9.48$ & $120.61 \pm 10.67$ & 0.203 \\
\hline Alc, $\%$ & $5.28 \pm 0.17$ & $5.26 \pm 0.16$ & 0.341 \\
\hline Insulin, $\mu \mathrm{IU} / \mathrm{ml}$ & $18.92 \pm 6.57$ & $11.48 \pm 4.70$ & $<0.001^{*}$ \\
\hline HOMA-IR & $3.98 \pm 1.42$ & $2.30 \pm 0.93$ & $<0.001 *$ \\
\hline Total cholesterol, mg/dl & $209.55 \pm 33.38$ & $205.01 \pm 45.39$ & 0.471 \\
\hline LDL-C, mg/dl & $138.73 \pm 28.13$ & $133.20 \pm 28.53$ & 0.219 \\
\hline HDL-C, mg/dl & $41.02 \pm 9.33$ & $49.52 \pm 11.20$ & $<0.001 *$ \\
\hline Triglycerides, mg/dl & $143.97 \pm 32.69$ & $111.40 \pm 31.70$ & $<0.001^{*}$ \\
\hline hs-CRP, mg/l & $1.24 \pm 0.54$ & $0.68 \pm 0.21$ & $<0.001^{*}$ \\
\hline $\mathrm{FSH}, \mathrm{mIU} / \mathrm{ml}$ & $7.10 \pm 1.71$ & $7.45 \pm 1.87$ & 0.224 \\
\hline $\mathrm{LH}, \mathrm{mIU} / \mathrm{ml}$ & $12.34 \pm 3.87$ & $7.58 \pm 2.67$ & $<0.001^{*}$ \\
\hline Estradiol, pg/ml & $51.11 \pm 11.93$ & $49.55 \pm 8.25$ & 0.340 \\
\hline Progesterone, $\mathrm{ng} / \mathrm{ml}$ & $1.09 \pm 0.22$ & $1.14 \pm 0.24$ & 0.221 \\
\hline Total-testosterone, $\mathrm{nmol} / 1$ & $2.92 \pm 0.41$ & $1.71 \pm 0.35$ & $<0.001 *$ \\
\hline SHBG, nmol/1 & $37.88 \pm 11.34$ & $69.25 \pm 15.21$ & $<0.001^{*}$ \\
\hline FAI, $\%$ & $8.14 \pm 1.69$ & $2.49 \pm 0.15$ & $<0.001^{*}$ \\
\hline DHEA-SO $_{4}, \mu \mathrm{g} / \mathrm{dl}$ & $178.01 \pm 59.65$ & $156.53 \pm 38.11$ & $0.008^{*}$ \\
\hline CIMT, mm & $1.01 \pm 0.43$ & $0.61 \pm 0.29$ & $<0.001^{*}$ \\
\hline
\end{tabular}

Results are given in mean $\pm S D$. a Independent samples t-test was used. A $P$ value of $<0.05$ was considered significant (*). Alc: Glycosylated hemoglobin; BMI: Body mass index; cIMT: Carotid intima media thickness; DHEA-S: Dehydroepiandrosterone sulfate; DBP: Diastolic blood pressure; FAI: Free androgen index; FBG: Fasting blood glucose, FSH: follicle-stimulating hormone; HDL-C: High density lipoprotein cholesterol; HOMA-IR: Homeostasis model assessment of insulin resistance; hs-CRP: High sensitivity $C$-reactive protein; $L D L-C$ : Low resistance; hs-CRP: High sensitivity C-reactive protein; LDL-C: Low
density lipoprotein cholesterol; LH: Luteinizing hormone; PCOS: Polycystic ovary syndrome; SBP: Systolic blood pressure; SHBG: Sex hormone-binding globulin; 2-h OGTT: 2-hour oral glucose tolerance test.
CIMT whereas fetuin-B negatively correlated with HDL-C and SHBG in women with PCOS only. Fetuin-B levels did not show any correlation with age, blood pressure, lipids profile, A1c, 2-h OGTT and other hormonal parameters.

\section{Multivariate regression analysis}

To verify independent associations between fetuin-B and correlated parameters, multiple linear regression analysis was performed in the whole study population (Table 3 ).
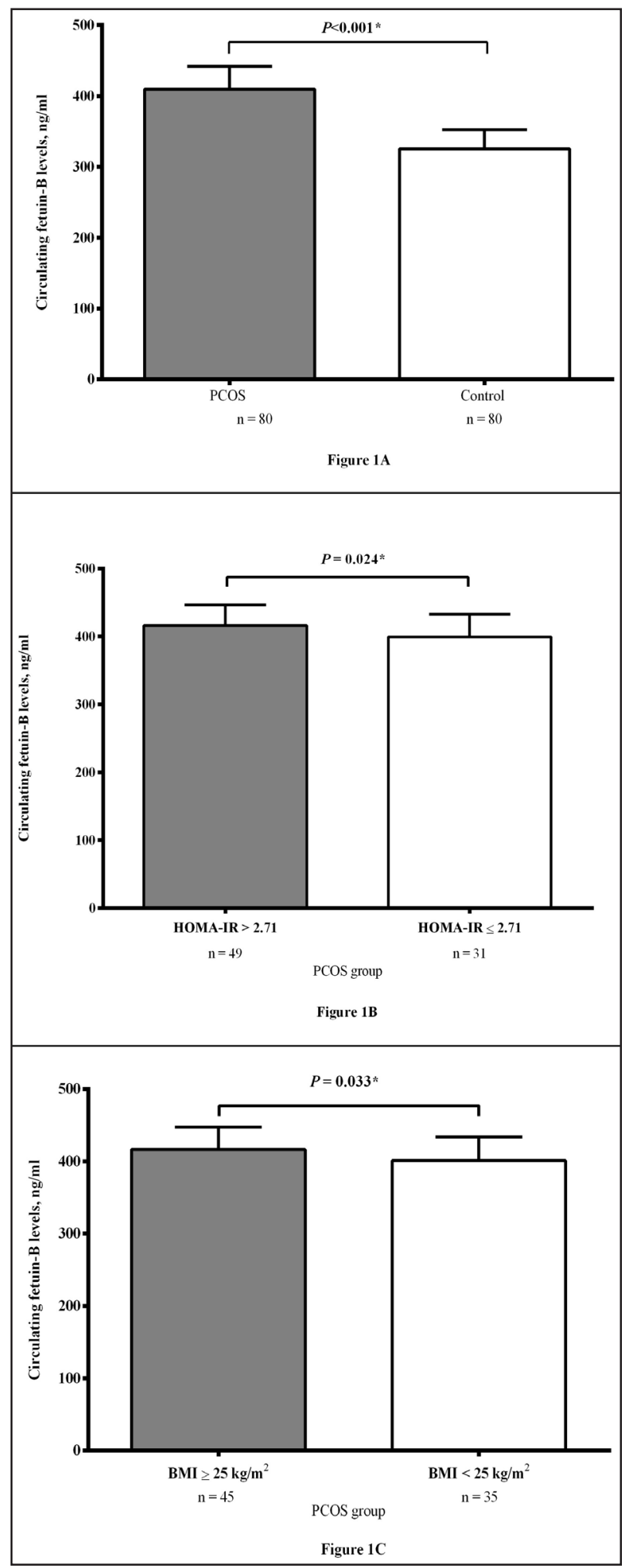

Figure 1: Circulating fetuin-B levels in PCOS and control groups. Figure 1B: Circulating fetuin-B levels in PCOS women with and without insulin resistance. Figure 1C: Circulating fetuin-B levels in PCOS women according to BMI (normal-weight: BMI $<25 \mathrm{~kg} / \mathrm{m} 2$; overweight/ obese: $\mathrm{BMI} \geq 25 \mathrm{~kg} / \mathrm{m} 2$ ). A P value of $<0.05$ was considered significant (*). 
Multiple linear regression analysis revealed that fetuin-B levels were positively associated with BMI, HOMA-IR, FAI and triglycerides whereas fetuin-B levels were negatively associated with HDL-C. The link between fetuin-B and hs-CRP was disappeared following adjustment with other correlated parameters.

Table 2: Correlation coefficient between fetuin-B levels and clinical parameters.

\begin{tabular}{|c|c|c|c|c|}
\hline & \multicolumn{4}{|c|}{ Fetuin-B } \\
\hline & \multicolumn{2}{|c|}{ PCOS } & \multicolumn{2}{|c|}{ Control } \\
\hline & $\mathrm{r}$ & $\mathrm{P}$ & $\mathrm{r}$ & $\mathrm{P}$ \\
\hline Age & 0.101 & 0.313 & 0.092 & 0.342 \\
\hline BMI & 0.214 & $0.007 *$ & 0.193 & $0.010^{*}$ \\
\hline Waist circumference & 0.198 & $0.011 *$ & 0.176 & $0.013 *$ \\
\hline SBP & 0.112 & 0.134 & 0.109 & 0.287 \\
\hline DBP & 0.093 & 0.246 & 0.087 & 0.289 \\
\hline Insulin & 0.324 & $0.003^{*}$ & 0.112 & 0.055 \\
\hline FBG & 0.142 & $0.024 *$ & 0.101 & 0.061 \\
\hline 2-h OGTT & 0.114 & 0.268 & 0.109 & 0.311 \\
\hline HOMA-IR & 0.209 & $0.015^{*}$ & 0.103 & 0.058 \\
\hline $\mathrm{A} 1 \mathrm{c}$ & 0.095 & 0.157 & 0.089 & 0.186 \\
\hline FSH & 0.067 & 0.387 & 0.072 & 0.312 \\
\hline LH & 0.125 & 0.078 & 0.106 & 0.119 \\
\hline Estradiol & 0.113 & 0.217 & 0.094 & 0.138 \\
\hline Progesterone & 0.117 & 0.201 & 0.103 & 0.242 \\
\hline DHEA-SO $_{4}$ & 0.121 & 0.066 & 0.084 & 0.125 \\
\hline Total-testosterone & 0.319 & $0.005^{*}$ & 0.107 & 0.071 \\
\hline SHBG & -0.108 & $0.038^{*}$ & -0.067 & 0.088 \\
\hline FAI & 0.178 & $0.027^{*}$ & 0.067 & 0.091 \\
\hline hs-CRP & 0.145 & $0.032 *$ & 0.083 & $0.044 *$ \\
\hline CIMT & 0.380 & $<0.001 *$ & 0.132 & 0.059 \\
\hline Total cholesterol & 0.115 & 0.083 & 0.107 & 0.127 \\
\hline LDL-C & 0.104 & 0.086 & 0.098 & 0.112 \\
\hline HDL-C & -0.151 & $0.038^{*}$ & -0.113 & 0.061 \\
\hline Triglycerides & 0.137 & $0.041^{*}$ & 0.102 & 0.058 \\
\hline
\end{tabular}

Pearson's correlation analysis was used. $r$ : Pearson's correlation coefficient. A P value of < 0.05 was considered significant (*). Alc: Glycosylated hemoglobin: BMI: Body mass index; cIMT: Carotid intima media thickness; DHEA-S: Dehydroepiandrosterone sulfate; DBP: Diastolic blood pressure; FAI: Free androgen index; FBG: Fasting blood glucose; FSH: follicle-stimulating hormone; HDL-C: High density lipoprotein cholesterol; HOMA-IR: Homeostasis model assessment of insulin resistance; $h s-C R P$ : High sensitivity $C$-reactive protein; LDL-C: Low density lipoprotein cholesterol: $L H$ : Luteinizing hormone; PCOS: Polycystic ovary syndrome; SBP: Systolic blood pressure: SHBG: Sex hormone-binding globulin; 2-h OGTT: 2-hour oral glucose tolerance test

Table 3: Multiple linear regression analysis of correlated variables with fetuin-B levels in all study population $(\mathrm{R} 2=0.416)$.

\begin{tabular}{|l|l|l|l|l|}
\hline \multicolumn{3}{|c|}{$95 \%$ CI } & \\
\hline Variables & $\beta$ & Lower & Upper & P \\
\hline BMI & 2.264 & 0.453 & 4.075 & $0.019^{*}$ \\
\hline HOMA-IR & 2.489 & 0.307 & 4.671 & $0.015^{*}$ \\
\hline Triglycerides & 0.654 & 0.078 & 1.230 & $0.046^{*}$ \\
\hline HDL-C & -0.471 & -0.712 & -0.231 & $0.040^{*}$ \\
\hline FAI & 2.678 & 0.515 & 4.841 & $0.022^{*}$ \\
\hline CIMT & 2.805 & 0.494 & 5.116 & $0.011^{*}$ \\
\hline Hs-CRP & 1.032 & -0.152 & 2.216 & 0.065 \\
\hline
\end{tabular}

Multiple linear regression analysis was used. $\beta$ : Unstandardized regression coefficient; CI: Confidence interval; $A$ P value of $<0.05$ was considered significant (*). BMI: Body mass index; CIMT: Carotid intima media thickness; FAI: Free androgen index; HDL-C: High density lipoprotein cholesterol; HOMA-IR: Homeostasis model assessment of insulin resistance; $h s-C R P$ : High sensitivity $C$-reactive protein
Multivariate Binary Logistic Regression Analysis

A logistic regression analysis was used to determine the link between fetuin-B levels and having PCOS risk (Figure 2).

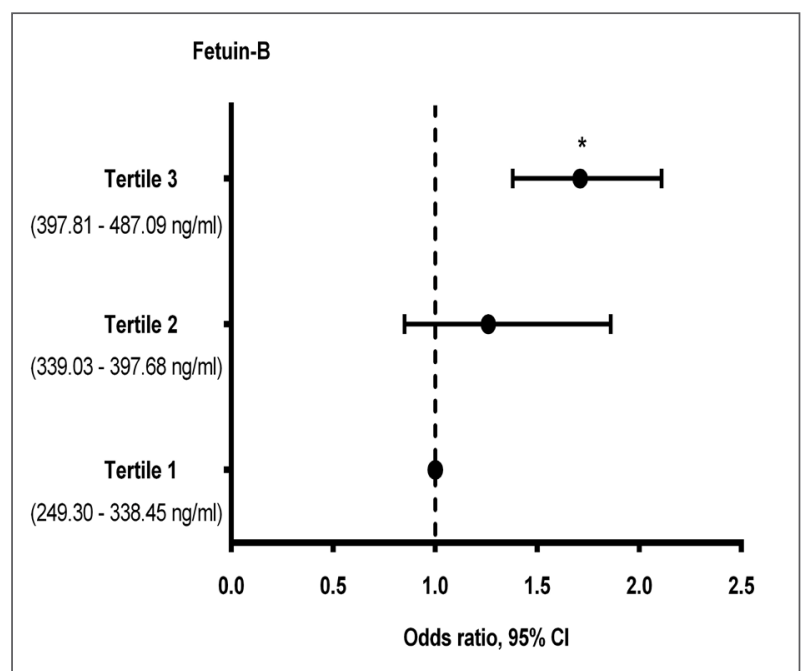

Figure 2: Association of fetuin-B with PCOS in adjusted models. Multivariate adjusted OR for having PCOS according to the tertiles of fractalkine (reference, the lowest tertile). OR: Odds Ratio; CI: Confidence Interval. A P value of $<0.05$ was considered significant (*).

The obtained results showed that the subjects with the highest tertile of fetuin-B tended to have increased possibility of having PCOS risk compared to those subjects with the lowest tertile of fetuin- $\mathrm{B}\left(\mathrm{OR}=1.71,95 \% \mathrm{CI}=1.38-2.11, \mathrm{P}=0.004^{*}\right)$ while participants with the second and the lowest tertiles of fetuin-B did not show any remarkable difference $(\mathrm{OR}=1.26,95 \% \mathrm{CI}=0.85-1.86, \mathrm{P}=$ $0.103)$.

\section{DISCUSSION}

In the present study, we found that circulating fetuin-B levels were significantly elevated in PCOS subjects with respect to the controls. PCOS subjects with insulin resistance had significantly increased circulating fetuin-B levels compared to those PCOS subjects without insulin resistance. Moreover, overweight/obese PCOS women had significantly higher circulating fetuin-B levels than lean PCOS women. Circulating fetuin-B levels showed an independently positive association with BMI, insulin resistance, FAI, CIMT and triglycerides whereas fetuin-B displayed an independently negative association with HDL-C. In addition, logistic regression analysis revealed that elevated levels of fetuin-B were associated with increased risk of having PCOS. Subjects with the highest tertile of fetuin-B levels showed 1.7 times more increased risk of having PCOS compared to those subjects with the lowest tertile of fetuin-B levels after adjusting for potential confounders.

Many women with PCOS have some degree of insulin resistance. Although, insulin resistance plays an important role in the pathogenesis of PCOS, the underlying mechanism remains incompletely understood. In the current study, we also found that insulin resistance was significantly elevated in women with PCOS compared to controls. A variety of molecules play crucial roles for 
the development of insulin resistance in women with PCOS $[1,2]$. Fetuin-B is introduced as a novel peptide hormone and preclinical and clinical data suggest that the peptide has a role in development of insulin resistance [4, 5]. In the present study, we found that circulating levels of fetuin-B were significantly elevated in PCOS subjects with respect to controls. Circulating fetuin-B levels were significantly higher in PCOS subjects with insulin resistance than in those PCOS subjects without insulin resistance. Moreover, we found an independently positive association between fetuin-B and insulin resistance. In accordance with our study, circulating fetuin-B levels were also found to be elevated in PCOS subjects compared to controls [18]. They also found that fetuin-B showed a positive correlation with insulin resistance and indices of liver steatosis in PCOS women. It was reported that elevated levels of fetuin-B associated with insulin resistance in NAFLD subjects [5]. PCOS subjects tend to have development of NAFLD [1, 2]. Therefore, we excluded both the controls and PCOS subjects having NAFLD to avoid the effect of NAFLD on the discovery of the relationship between PCOS and fetuin-B. We clarified that the relation of PCOS and fetuin-B was independent from NAFLD. Consistently, we found that fetuin-B displayed independent association with FAI. Moreover, having PCOS risk was increased in parallel with elevation of fetuin-B independently. Although the physiological roles of fetuin-B in the ovulation system have not been elucidated yet, based on these observations, it is reasonable to speculate that fetuin-B may contribute to the development of PCOS independently. In addition, the relation of fetuin-B and reproductive system has been reported $[11,19]$. In a study by Fang et al., they reported that fetuin-B levels in serum and follicular fluid were correlated with fertilization rate in IVF cycles [19]. These data suggest that fetuin-B may involve in reproductive system via diverse pathophysiological pathways.

PCOS subjects tend to have an increased risk of developing cardiovascular diseasees [20, 21]. It is essential to define the individual cardiovascular risks for PCOS women. For this reason, many biomarkers have been identified to predict risk of cardiovascular events in women with PCOS [22, 23]. CIMT is a good indicator of cardiovascular risk and is strongly associated with conventional cardiovascular risk factors $[5,6]$. In the present study, we found that CIMT was increased in PCOS subjects compared to controls. Growing evidence suggest that there is a link between fetuin-B and cardiovascular disorders [9, 24]. Moreover, fetuin-B increases inflammation in vascular plaque and also causes vascular plaque vulnerable [10]. In a study by Zhu et al., serum fetuin-B levels were found to be significantly elevated in patients with coronary artery disease compared to healthy controls. Moreover, they reported that fetuin-B showed an independent association with the presence of coronary artery disease and acute coronary syndrome [9]. In another study by Jung et al., they demonstrated that serum fetuin-B levels were significantly higher in subjects with acute myocardial infarction than in subjects with stable angina pectoris [10]. Herein, we found an independent relationship between fetuin-B and CIMT. In the light of these data, it is reasonable that fetuin-B may play an important role in atherosclerotic process of women with PCOS.

Disturbance of lipid metabolism is commonly appeared in PCOS subjects, HDL-C levels are decreased and triglycerides levels are increased in PCOS subjects $[1,2]$. We found that circulating HDL-C levels were lower whereas triglycerides levels were higher in PCOS women than in controls consistently. Moreover, we demonstrated that fetuin-B levels showed an independently positive link with triglycerides whereas the peptide levels displayed an independently negative link with HDL-C. Consistently, a link between fetuin-B and lipid metabolism was reported previously [9]. Elevation of fetuin-B in PCOS women may contribute to disturbances of lipid metabolism.

There are some limitations to the current study. We used the less invasive HOMA-IR method, although it is inferior to the clamp technique. We came across with some limitations in our study. Although there is uncertainty with not obtaining causality using cross-sectional designed study, it opens a novel approach toward understanding whether there is a link between molecules and disorders. Circulating levels of fetuin-B were not measured during menstrual cycle to clarify whether there was altered levels of fetuin-B in women with normal menstrual cycle.

In conclusion, elevated levels of fetuin-B were associated with hormonal-metabolic disturbance and cardiovascular risk in women with PCOS. Fetuin-B may contribute to the development of cardiovascular events and metabolic disturbances in PCOS patients. Nevertheless, the underlying mechanisms explaining the present results require further investigation.

\section{Abbreviations}

BMI: Body mass index; CI: Confidence interval; CIMT: carotid intima media thickness; CV: Coefficient of variability; DHEA-S: Dehydroepiandrosterone sulfate; DBP: Diastolic blood pressure; FAI: Free androgen index; FBG: Fasting blood glucose; FG: Ferriman-Gallwey; FSH: follicle-stimulating hormone; HDL-C: High density lipoprotein cholesterol; HOMA-IR: Homeostasis model assessment of insulin resistance; Hs-CRP: High sensitivity C-reactive protein; LDL-C: Low density lipoprotein cholesterol; LH: Luteinizing hormone; NAFLD: Non-alcoholic fatty liver disease; OR: Odds ratio; PCOS: Polycystic ovary syndrome; SBP: Systolic blood pressure; SHBG: Sex hormone-binding globulin, T2DM: Type 2 diabetes mellitus.

\section{REFERENCES}

1. Azziz R, Woods KS, Reyna R, Key TJ, Knochenhauer ES, Yildiz BO. The prevalence and features of the polycystic ovary syndrome in an unselected population. J Clin Endocrinol Metab [Internet]. 2004 Jun [cited 2014 Mar 2];89(6):2745-9. Available from: http://www.ncbi.nlm.nih.gov/pubmed/15181052 
2. Stepto NK, Cassar S, Joham AE, Hutchison SK, Harrison $C L$, Goldstein RF, et al. Women with polycystic ovary syndrome have intrinsic insulin resistance on euglycaemic-hyperinsulaemic clamp. Hum Reprod [Internet]. 2013 Mar 1;28(3):777-84. Available from: http://humrep.oxfordjournals.org/lookup/ doi/10.1093/humrep/des463

3. Hoffman LK, Ehrmann DA. Cardiometabolic features of polycystic ovary syndrome. Nat Clin Pract Endocrinol Metab [Internet]. 2008 Apr [cited 2014 Aug 9]:4(4):215-22. Available from: http://www.ncbi.nlm.nih.gov/pubmed/18250636

4. Goodarzi MO, Dumesic DA, Chazenbalk G, Azziz R. Polycystic ovary syndrome: etiology, pathogenesis and diagnosis. Nat Rev Endocrinol. 2011;7(4):219-31.

5. Meex RC, Hoy AJ, Morris A, Brown RD, Lo JCY, Burke M, et al. Fetuin B Is a Secreted Hepatocyte Factor Linking Steatosis to Impaired Glucose Metabolism. Cell Metab [Internet]. 2015 Dec;22(6):1078-89. Available from: https://linkinghub.elsevier com/retrieve/pii/S1550413115004805

6. Olivier E, Soury E, Ruminy P, Husson A, Parmantier F, Daveaum, et al. Fetuin-B, a second member of the fetuin family in mammals. Biochem J [Internet]. 2000 Sep 1;350(2):589-97. Available from: http://www.biochemj.org/cgi/doi/10.1042/ bj3500589

7. Li Z, Lin M, Liu C, Wang D, Shi X, Chen Z, et al. Fetuin-B links nonalcoholic fatty liver disease to type 2 diabetes via inducing insulin resistance: Association and path analyses. Cytokine [Internet]. 2018 Aug;108:145-50. Available from: https://linkinghub.elsevier.com/retrieve/pii/S1043466618301091

8. Kralisch S, Hoffmann A, Lössner U, Kratzsch J, Blüher M, Stumvoll $M$, et al. Regulation of the novel adipokines/ hepatokines fetuin A and fetuin B in gestational diabetes mellitus. Metabolism [Internet]. 2017;68:88-94. Available from: http://www. ncbi.nlm.nih.gov/pubmed/28183456

9. Zhu K, Wang Y, Shu P, Zhou $Q$, Zhu J, Zhou W, et al. Increased serum levels of fetuin $B$ in patients with coronary artery disease. Endocrine [Internet]. 2017 Oct;58(1):97-105. Available from: http://www.ncbi.nlm.nih.gov/pubmed/28822077

10. Jung SH, Won K-J, Lee KP, Kim H-J, Seo E-H, Lee HM, et al. The serum protein fetuin-B is involved in the development of acute myocardial infarction. Clin Sci [Internet]. 2015 Jul 1;129(1):27-38. Available from: http://www.clinsci.org/cgi/ doi/10.1042/CS20140462

11. Dietzel E, Floehr J, Van de Leur E, Weiskirchen R, Jahnen-Dechent $W$. Recombinant fetuin-B protein maintains high fertilization rate in cumulus cell-free mouse oocytes. Mol Hum Reprod [Internet]. 2017;23(1):25-33. Available from: http:// www.ncbi.nlm.nih.gov/pubmed/27733489

12. Revised 2003 consensus on diagnostic criteria and longterm health risks related to polycystic ovary syndrome (PCOS). Hum Reprod [Internet]. 2004 Jan 1;19(1):41-7. Available from: http://humrep.oxfordjournals.org/lookup/doi/10.1093/humrep/ deh098

13. Ferriman D, Gallwey JD. Clinical assessment of body hair growth in women. J Clin Endocrinol Metab [Internet]. 1961 Nov [cited 2014 Jun 18];21:1440-7. Available from: http://www. ncbi.nlm.nih.gov/pubmed/13892577
14. Matthews DR, Hosker JP, Rudenski AS, Naylor BA, Treacher DF, Turner RC. Homeostasis model assessment: insulin resistance and beta-cell function from fasting plasma glucose and insulin concentrations in man. Diabetologia [Internet]. $1985 \mathrm{Jul}$ [cited $2014 \mathrm{Jul}$ 13];28(7):412-9. Available from: http://www. ncbi.nlm.nih.gov/pubmed/3899825

15. Sidhu PS, Desai SR. A simple and reproducible method for assessing intimal-medial thickness of the common carotid artery. Br J Radiol. 1997;70(JAN.):85-9.

16. Faul F, Erdfelder E, Lang A-G, Buchner A. G*Power 3: A flexible statistical power analysis program for the social, behavioral, and biomedical sciences. Behav Res Methods [Internet]. 2007 May;39(2):175-91. Available from: http://www.springerlink.com/index/10.3758/BF03193146

17. Geloneze B, Repetto EM, Geloneze SR, Tambascia MA, Ermetice MN. The threshold value for insulin resistance (HOMA-IR) in an admixtured population. Diabetes Res Clin Pract [Internet]. 2006 May;72(2):219-20. Available from: http://linkinghub.elsevier.com/retrieve/pii/S0168822705004213

18. Adamska A, Polak AM, Krentowska A, Łebkowska A, Hryniewicka $J$, Leśniewska $M$, et al. Increased serum fetuin- $B$ concentration is associated with HOMA- $\beta$ and indices of liver steatosis in women with polycystic ovary syndrome: a pilot study. Endocr Connect [Internet]. 2019 Jul 1; Available from: http:// www.ncbi.nlm.nih.gov/pubmed/31307012

19. Fang $L, H u X, C u i L, L v P, M a X$, Ye Y. Serum and follicular fluid fetuin-B levels are correlated with fertilization rates in conventional IVF cycles. J Assist Reprod Genet [Internet]. 2019 Jun;36(6):1101-7. Available from: http://www.ncbi.nlm.nih.gov/ pubmed/31073723

20. Christian RC, Dumesic DA, Behrenbeck T, Oberg AL, Sheedy PF, Fitzpatrick LA. Prevalence and predictors of coronary artery calcification in women with polycystic ovary syndrome. $J$ Clin Endocrinol Metab. 2003;88(6):2562-8.

21. Aziz M, Sidelmann JJ, Faber J, Wissing M-LM, Naver K V, Mikkelsen A-L, et al. Polycystic ovary syndrome: cardiovascular risk factors according to specific phenotypes. Acta Obstet Gynecol Scand [Internet]. 2015 Oct;94(10):1082-9. Available from: http://www.ncbi.nlm.nih.gov/pubmed/26123797

22. Toulis KA, Goulis DG, Mintziori G, Kintiraki E, Eukarpidis E, Mouratoglou S-A, et al. Meta-analysis of cardiovascular disease risk markers in women with polycystic ovary syndrome. Hum Reprod Update [Internet]. 2011 Nov 1:17(6):741-60. Available from: http://humupd.oxfordjournals.org/cgi/doi/10.1093/ humupd/dmr025

23. Polak JF, Szklo M, Kronmal RA, Burke GL, Shea S, Zavodni AEH, et al. The Value of Carotid Artery Plaque and Intima-Media Thickness for Incident Cardiovascular Disease: The Multi-Ethnic Study of Atherosclerosis. J Am Heart Assoc [Internet]. $2013 \mathrm{Apr}$ 8;2(2):e000087-e000087. Available from: http://jaha.ahajournals.org/cgi/doi/10.1161/ JAHA.113.000087

24. Li Z, He C, Liu Y, Wang D, Lin M, Liu C, et al. Association of Fetuin-B with Subclinical Atherosclerosis in Obese Chinese Adults. J Atheroscler Thromb [Internet]. 2019; Available from: https://www.jstage.jst.go.jp/article/jat/advpub/0/advpub_49619/ article 